\title{
Dominik Sadtakowski*
}

\section{ZARZĄDZANIE RYZYKIEM W SYSTEMIE PŁATNICZYM}

Z a r y s t r e ś c i: W niniejszym artykule scharakteryzowane zostały główne typy ryzyka jakie mogą wystąpić w systemie płatniczym oraz rozwiązania systemowe pozwalające na minimalizację ich skutków. W pracy szczególny nacisk położny został na analizę systemów płatności wysokokwotowych, gdyż ze względu na powiązanie międzysystemowe to one $\mathrm{w}$ momencie zaistnienia poważnego incydentu w systemie płatniczym stanowią swoistego rodzaju bufor, który zapobiega przeniesieniu powstałych fluktuacji na inne systemy lub ich uczestników. Niniejszy artykuł ma charakter przeglądowy, a treści w nim zawarte bazują na dostępnej literaturze przedmiotu, raportach branżowych oraz aktach prawnych i regulacjach dotyczących systemów płatności.

S ło w a k 1 u c z o w e: System płatniczy, system płatności, systemy wysokokwotowe, RTGS, DNS.

K 1 a s y fi k a c j J E L: L 21; G29;

\section{WSTĘP}

System płatniczy stanowi jeden z najważniejszych elementów infrastruktury finansowej każdej nowoczesnej gospodarki. W przypadku architektury płatniczej, w ramach której następuje transfer gotówki niezwykle ważne jest utrzymanie jej wysokiej efektywności przy zachowaniu najwyższych standardów bezpieczeństwa. Kluczowe miejsce w każdym systemie płatniczym zajmuje system płatności wysokokwotowych, w którym dokonywane są rozliczenia transakcji międzybankowych, operacje polityki pieniężnej oraz rozrachunek powiązanych systemów płatności detalicznych. Wysoki stopień korelacji w systemie płatniczym powoduje, iż wszelkie fluktuacje w systemach detalicznych powodują przenoszenie ryzyka na system centralny. $Z$ tego względu

\footnotetext{
* Adres do korespondencji: Dominik Sadłakowski, Uniwersytet Mikołaja Kopernika w Toruniu, Wydział Nauk Ekonomicznych i Zarządzania, Katedra Zarządzania Finansami, ul. Gagarina 13a, 87-100 Toruń, e-mail: dominik.sadlakowski@gmail.com.
} 
wdrażanie nowych rozwiązań technologicznych oraz mechanizmów rozliczeń i rozrachunku transakcji stanowi jeden z priorytetów rozwoju systemów wysokokwotowych.

Kwestia zarządzania ryzykiem w systemie płatniczym jest niezwykle złożonym problemem o charakterze interdyscyplinarnym, który wymaga wieloaspektowej analizy zarówno na płaszczyźnie nauk ekonomicznych, prawnych jak i nauk ścisłych. Niniejszy artykuł ma na celu systematyzację wiedzy oraz uzupełnienie braków w literaturze przedmiotu z zakresu funkcjonowania systemów płatniczych. Przedstawione w nim koncepcje teoretyczne oraz aspekty prawne są próbą syntetycznego przedstawienia zjawiska ryzyka w systemie płatniczym oraz mechanizmów pozwalających na jego minimalizację.

Praca została podzielna na dwie części. W pierwszej omówiono rolę systemu płatniczego oraz przedstawiono formy nadzoru którymi jest objęty. W drugiej natomiast porównane ze sobą zostały wybrane typy systemów płatności wysokokwotowych. Niniejszy artykuł ma charakter teoretyczny, przy jego opracowaniu wykorzystano dostępną literaturę przedmiotu, raporty branżowe, akty prawne oraz dane statystyczne Narodowego Banku Polskiego.

\section{CHARAKTERYSTYKA SYSTEMU PŁATNICZEGO ORAZ FORMY JEGO NADZORU}

System płatniczy stanowi unikalną strukturę połączonych ze sobą elementów, która zapewnia nieprzerwaną cyrkulację pieniądza w gospodarce. Powołując się na definicję zaproponowaną przez Adama Tochmańskiego [2013, s. 15] można go określić jako zestaw instrumentów płatniczych, pośredników, zasad, procedur oraz najczęściej międzybankowych systemów transferu funduszy wykorzystywanych do zapewnienia obiegu pieniadza $w$ danym kraju lub obszarze wspólnej waluty. Architektura systemu płatniczego jest wypadkową specyficznych cech gospodarczych danego kraju na którą wpływ mają m.in. takie czynniki jak: stopień rozwój sektora finansowego, umiędzynarodowienie, czy potrzeby rynkowe. Mimo dostrzegalnych różnić w infrastrukturze krajowych systemów płatniczych można wyszczególnić pewien zestaw elementów wspólnych, które warunkują istnienie systemu płatniczego, są to:

- instrumenty płatnicze, służące transferowi pieniądza w gospodarce;

- regulacje i standardy prawne określające zasady funkcjonowania instrumentów płatniczych oraz mechanizmu transferu płatności i funkcjonowania rynku usług płatniczych;

- instytucje, które prowadzą rachunki i pośredniczą płatnościom (banki centralne oraz komercyjne);

- podmioty dokonujące kompensaty oraz rozrachunku zleceń płatniczych [Iwańczuk, 2011, s. 38]. 
Z perspektywy stabilności finansowej kraju niezwykle istotne jest ciągłe monitorowanie podmiotów stanowiących architekturę systemu płatniczego oraz wdrażanie nowych rozwiązań pozwalających ograniczyć lub wyeliminować potencjalne przyczyny powstawania ryzyka systemowego. Wczesna identyfikacja ryzyka w systemie płatniczym jest niezwykle trudna ze względu na dynamikę transakcji w nim dokonywanych. Aby uzmysłowić sobie skalę obrotu w systemie płatniczym można posłużyć się przykładem polskiego systemu płatniczego. Szacuje się, że wartość zleceń płatniczych zrealizowanych w krajowym systemie wysokokwotowym (Sorbnet2) wyniosła w 2016 r. ponad 70 bln zł, co stanowi 40 krotność krajowego PKB [Ocena funkcjonowania polskiego systemu..., 2016, s. 16-17]. Świadczy to o niebagatelnej roli infrastruktury płatniczej dla zapewnienia prawidłowego funkcjonowania zarówno sektora finansowego jak i również podmiotów sfery realnej. Schemat współzależności między elementami systemu płatniczego a rynkiem, został przedstawiony na rysunku 1.

Rysunek 1. Schemat oddziaływania systemu płatniczego na gospodarkę

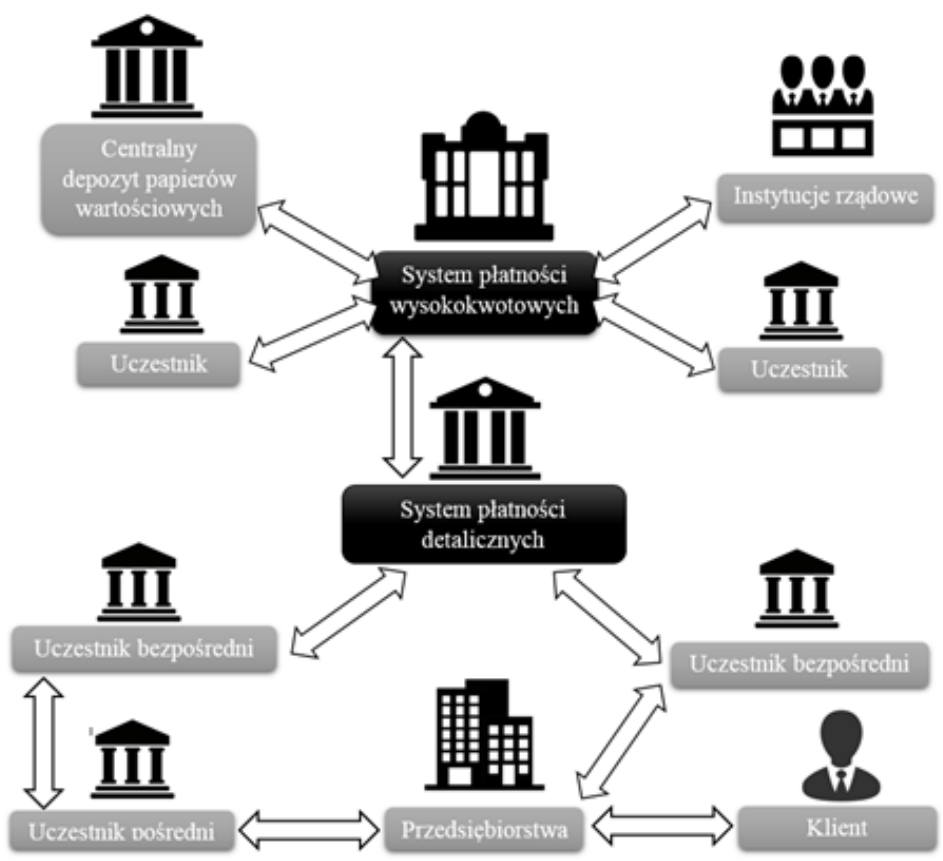

Źródło: opracowanie własne na podstawie: White paper: Reducing risk and increasing resilience in RTGS payment systems (2014), www.swift.com [27.04.2017].

Obecnie w większości krajów obowiązuje zasada dualizmu nadzoru nad systemem płatniczym, który sprawowany jest przez banki centralne oraz podmioty odpowiedzialne za kontrolę nad rynkiem kapitałowym. Pierwszy z nich określany mianem nadzoru systemowego (ang. oversight), prowadzony jest 
przez banki centralne i obejmuje swym zakresem systemy płatności, systemy rozliczeń i rozrachunku papierów wartościowych oraz schematy płatnicze. W ramach jego sprawowania podejmuje się działania zmierzające do zapewnienia, by funkcjonowanie elementów architektury finansowej było bezpieczne i zgodne z obowiązującymi normami prawnymi [Nadzór systemowy $w$ zakresie systemu płatniczego, 2017, s. 4].

Nadzór ostrożnościowy (ang. supervision) ukierunkowany jest na monitorowanie operatorów poszczególnych systemów oraz partycypujących w nich uczestników. Mowa tu w szczególności o bankach, instytucjach płatniczych, instytucjach pieniądza elektronicznego oraz innych podmiotach mogących prowadzić działalność płatniczą. Nadzorca kontrolując podmioty sektora finansowego ma za zadanie weryfikację bezpieczeństwa zgromadzonych tam środków pieniężnych. Instytucje objęte nadzorem sprawdzane są m.in. pod kątem ich ekspozycji na ryzyko, wartości zgromadzonych funduszy własnych oraz sposobu prowadzenia strategii finansowej [Górka, 2013, s. 22].

Można zatem przyjąć, iż dualizm nadzoru nad systemem płatniczym uzależniona jest od specyfiki i skali zagrożeń, które potencjalnie mogą w nim zaistnieć. Z perspektywy stabilności krajowego systemu finansowego kluczowe jest zapobieganie powstawianiu ryzyka systemowego. Ma ono miejsce w sytuacji, gdy następuje niewypłacalność i brak możliwości do uregulowania zobowiązań któregoś z systemowo ważnych uczestników systemu płatności. Upadłość podmiotu tego typu (posiadającego znaczne udziały w rynku) może oddziaływać na powiązanych z nim uczestników, przez co mogą oni nie być w stanie zrealizować swoich zobowiązań płatniczych w momencie gdy staną się wymagalne. Dochodzi zatem do efektu zarażania, a więc niekontrolowanego rozprzestrzeniania się ryzyka na powiązane instytucje finansowe. Skutkiem takiego stanu rzeczy mogą być zatory płatnicze, spadek zaufania do systemu, a w skrajnym przypadku przeniesienie powstałych w ten sposób zaburzeń systemowych na sferę gospodarki realnej [Górka, 2013, s. 21-22]. Ryzyko systemowe jest finalnym etapem destabilizacji systemu płatniczego, na którego materializację ma wpływ szereg czynników. Poniżej opisano wybrane typy ryzyka, które mogą oddziaływać na stabilność systemu płatniczego.

Ryzyko kredytowe, ma miejsce wówczas, gdy strona transakcji nie jest w stanie uregulować swojego zobowiązania w wyznaczonym terminie zapadalności, ani też w żadnym innym późniejszym terminie. W skrajnych sytuacjach może się to wiązać się z permanentną niewypłacalnością dłużnika [Systemy rozrachunku papierów wartościowych w Polsce i Unii Europejskiej, 2009, s. 24].

Ryzyko płynności występujące, gdy strona transakcji nie jest w stanie uregulować swojego zobowiązania na czas lub w jego całkowitej wysokości. W odróżnieniu od ryzyka kredytowego wierzyciel, nie jest jednak niewypłacalny i możliwe jest uregulowanie jego zobowiązań w przyszłości [Art. 2, ust. 
9, Rozporządzenie Europejskiego Banku Centralnego (UE) nr 795/2014 z dnia 3 lipca 2014 r.].

Ryzyko operacyjne w systemie płatniczym definiowane jest jako ryzyko poniesienia nieoczekiwanej straty, która wiąże się z zaistnieniem błędów ludzkich, wadliwością sprzętu technicznego lub nieprzewidzianym zdarzeniem zewnętrznym [Systemy rozrachunku..., s. 24].

Ryzyko prawne wynika ze stosowania przepisów ustawowych lub wykonawczych, prawdopodobieństwo jego zaistnienia może wzrosnąć w wyniku wdrażania nowych regulacji lub znacznych zmian w bieżącej legislacji [Art. 2, ust. 7, Rozporządzenie...].

Ryzyko powiernicze, czyli ryzyko poniesienia straty na aktywach powierzonych powiernikom na skutek ich niewypłacalności, niedbalstwa, oszustwa, złego zarządzania kapitałem przez powiernika (subpowiernika) lub niewłaściwej ewidencji prowadzonej przez ten podmiot [Art. 2, ust. 11, Rozporządzenie...].

Ryzyko korelacji wynikające z ekspozycji podmiotu wobec innego uczestnika systemu lub emitenta w sytuacji, gdy zabezpieczenia złożone przez tego uczestnika lub wyemitowane przez emitenta są ściśle skorelowane z jego ryzykiem kredytowym [Art. 2, ust. 38, Rozporządzenie...].

Ryzyko inwestycyjne jest związane z możliwością poniesienia straty przez operatora lub uczestnika systemu płatności w sytuacji inwestycji środków własnych lub środków innych uczestników [Art. 2, ust. 12, Rozporządzenie...].

Ryzyko rynkowe wynika z możliwości poniesienia straty na pozycjach bilansowych i pozabilansowych uczestnika systemu na skutek wahania cen rynkowych [Art. 2, ust. 13, Rozporządzenie...].

Ryzyko podstawowe ma miejsce, gdy kontrahent utraci kwotę równą wartości transakcji. Materializuje się ono w sytuacji braku otrzymania zapłaty za przekazane aktywa lub dokonaniu nieodwołalnej płatności za aktywa, ale ich nie otrzymaniu [Art. 2, ust. 32, Rozporządzenie...].

Rysunek 2. Klasyfikacja ryzyka w systemie płatniczym

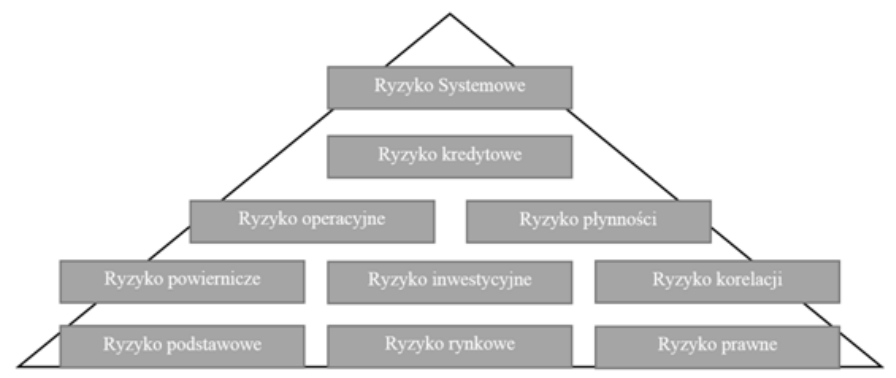

Źródło: opracowanie własne.

Specyficzną cechą ryzyka $\mathrm{w}$ systemie płatniczym jest również to, że ma ono charakter kaskadowy. Oznacza to, że materializacja któregoś 
z zagrożeń systemowych może przyczynić się do powstania ryzyka w obszarach powiązanych. Opisane powyżej typy ryzyka mogą wystąpić w niemal każdym systemie płatności oraz systemie rozliczeń i systemie rozrachunku papierów wartościowych. Incydenty powstałe na skutek ich materializacji mogą mieć jednak zróżnicowany wpływ na funkcjonowanie systemu płatniczego. Z tego względu podmioty stanowiące infrastrukturę płatniczą można poddać swoistego rodzaju gradacji, ze względu na ich istotność systemową. Polityka sprawowania przez Narodowy Bank Polski nadzoru systemowego $w$ zakresie systemu płatniczego (2015) określa czynniki pozwalające dokonać klasyfikacji elementów architektury płatniczej z perspektywy ich istotności dla funkcjonowania systemu płatniczego:

1. stopień oddziaływania na krajowy rynek finansowy, który oceniany jest na podstawie oceny wielkości funkcjonującego systemu oraz stopnia jego korelacji z uczestnikami rynku finansowego;

2. poziom penetracji rynku;

3. obszar oddziaływania, a więc weryfikacja czy dany system ma charakter transgraniczny oraz ocena potencjalnego ryzyka, które może wynikać z owych powiązań międzynarodowych;

4. fakt przeprowadzania rozrachunku na rzecz innej infrastruktury rynku finansowego.

\section{MECHANIZMY ZARZĄDZANIA RYZYKIEM W SYSTEMACH PŁATNOŚCI WYSOKOKWOTOWYCH}

Kluczowe miejsce w każdym systemie płatniczym zajmuje system płatności wysokokwotowych (large-value payment systems), w którym dokonywane są rozliczenia oraz rozrachunek transakcji międzybankowych. Jego sprawne funkcjonowanie jest niezwykle ważne z perspektywy stabilności finansowej kraju, rynku kapitałowego oraz powiązanych z nim systemów płatniczych i rozrachunku papierów wartościowych. System wysokokwotowy pełni również funkcję swoistego bufora zabezpieczającego, który w sytuacjach kryzysowych ma zapobiegać przenoszenia się ryzyka na innych uczestników systemu płatniczego. Systemy płatności wysokokwotowych można podzielić ze względu na długość opóźnienia między zainicjowaniem płatności, a jej rozliczeniem z tytułu dostarczenia funduszy do banku centralnego [Khandelwal, 2007, s. 9]. Poszczególne typy systemów różnią się od siebie z perspektywy ich efektywności, zapotrzebowania na płynność oraz ekspozycji na ryzyko.

W początkowym etapie tworzenia infrastruktury płatniczej dominowały systemy bazujące na zasadzie odroczonego rozrachunku netto (ang. deferred net settlemen systems). Mechanizm funkcjonowania owych systemów oparty jest o cykle rozliczeniowe, o zdefiniowanych interwałach czasowych, w czasie któ- 
rych następuje przekazywanie zleceń płatniczych miedzy uczestnikami systemu. [Glossary of terms related..., 2009,s. 9]. Rozrachunek odbywa się natomiast w sesjach podczas których ustalana jest indywidualna pozycja netto każdego uczestnika, stanowi ona sumę zobowiązań wobec pozostałych uczestników systemu skorygowaną o wysokość należności. Następnie dochodzi od uznania bądź obciążenia rachunku uczestnika [System płatności natychmiastowych, 2015, s. 11]. Główną zaletą tego typu rozwiązań jest dużo mniejsze zapotrzebowanie na płynność, niż w przypadku systemów RTGS, jednakże opóźnienia wynikające $\mathrm{z}$ przesunięcia rozrachunku w czasie mogą powodować wyższą ekspozycję na ryzyko np. w wyniku niewypełnienia zobowiązania przez któregoś z uczestników [Wilson, 2004, s. 7].

$\mathrm{W}$ odpowiedzi na potrzebę podniesienia bezpieczeństwa w systemie wysokokwotowym powstał mechanizm rozrachunku brutto w czasie rzeczywistym (ang. real time gross setelment systems) w ramach którego transfer środków między uczestnikami następuje w przeciągu zaledwie kilku sekund od jego inicjacji. W przypadku systemów tego typu nie dochodzi do kompensaty zleceń płatniczych, co oznacza, że każde z nich jest przetwarzane i księgowane indywidualnie. Rozrachunek w systemach RTGS charakteryzuje się tym, iż jest on bezwarunkowy, co oznacza że w przypadku zainicjowania zlecenia beneficjent bezwzględnie otrzyma środki, oraz nieodwołalny - przetworzonej transakcji nie można cofnąć [Bech, Preisig, Soramäki, 2008, s. 59]. Wadą systemów tego typu są bardzo duże koszty związane z utrzymywaniem zawansowanej sieci telekomunikacyjnej pozwalającej na przetwarzanie transakcji w ciągu zaledwie kilku sekund od ich zainicjowania. Problemem jest również bardzo duże zapotrzebowanie na płynność, które wynika z faktu rozrachowywania każdej transakcji z osobna. Mimo to, dzięki rozrachunkowi w czasie rzeczywistym doszło do znacznego obniżenia ryzyka kredytowego [System płatności natychmiastowych, 2015, s. 14-16].

Rysunek 3. Porównanie mechanizmów rozliczeń międzybankowych w systemie RTGS oraz DNS
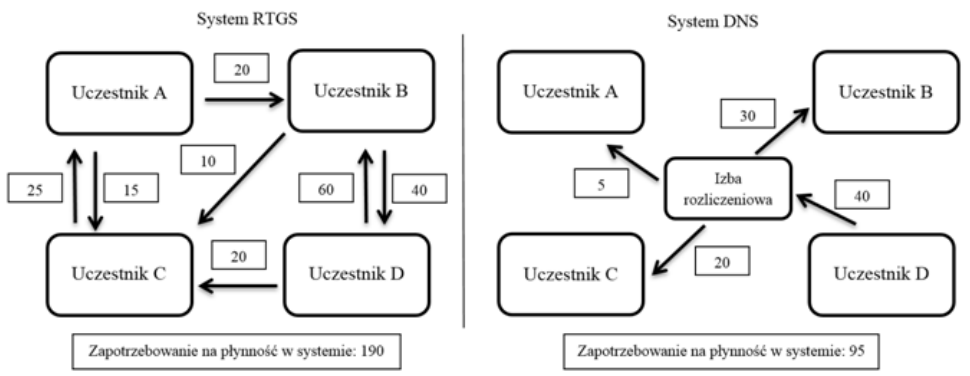

Źródło: opracowanie własne.

Próbą osiągnięcia kompromisu między zapotrzebowaniem na płynność, a ograniczeniem ryzyka systemowego, przy zachowaniu relatywnie wysokiej 
efektywności systemu było stworzenie tzw. systemów hybrydowych, które łączą w sobie najlepsze cechy wcześniejszych opisanych rozwiązań technologicznych. W systemach tych kluczowe znacznie ma centralny punkt rozliczania transakcji, którego zadaniem jest kolejkowanie i netowanie płatności w trybie ciągłym lub wielosesyjnym. W sytuacji, gdy pozycje debetowe uczestników są zabezpieczone saldem na rachunku rozliczeniowym lub mają pokrycie w płatnościach przychodzących następuje rozliczenie zleceń płatniczych [New developments in large-value payment systems, 2005, s. 13]. W przypadku niedoborów płynności transakcje te są przesuwane na następną sesję. Rozwiązanie bazujące na natychmiastowym nettingu pozycji uczestników pozwala zredukować zapotrzebowania na płynność w systemie płatniczym zapewniając jednocześnie jego wysokie bezpieczeństwo. Zastosowany w tym systemie mechanizm zabezpieczania płatności bazuje na dwóch zasadach, po pierwsze - w sesji rozliczeniowej uwzględnia są tylko płatności, które posiadają pokrycie oraz tego, że rozrachunek następuje natychmiastowo po nettingu pozycji uczestników [Barvell, 2002, s. 12-13].

\section{ZAKOŃCZENIE}

Nie ulega wątpliwości, iż systemy płatnicze ze względu na swoje miejsce $\mathrm{w}$ architekturze finansowej mają kluczowe znacznie dla efektywnego funkcjonowania każdej nowoczesnej gospodarki rynkowej. Ich efektywność warunkowana jest w znacznej mierze niezawodnością systemów wysokokwotowych, które ze względu na wartość i specyfikę dokonywanych w nich transakcji obarczone są wysoką ekspozycją na ryzyko. Fakt ten warunkuje nieustanną ewolucję systemów wysokokwotowych w celu dostosowania ich do zmieniających się warunków rynkowych. Opisane w pracy mechanizmy rozliczania i rozrachunku transakcji wskazują, iż rozwój systemów wysokokwotowych ukierunkowany jest $\mathrm{w}$ stronę rozwiązań zapewniających najwyższy stopień bezpieczeństwa, a więc tych bazujących na zasadzie ostateczności rozrachunku. Zapobiegają one powstawaniu ryzyka kredytowego, które stanowi główny czynnik destabilizujący system płatniczy. Systemy RTGS uważane są zatem za jedne z najbezpieczniejszych systemów płatności wykorzystywanych do obsługi transakcji wysokokwotowych. Zdaniem Autora dalszy rozwój systemów płatności będzie oparty o modyfikację i usprawnianie owej technologii, czego przykładem mogą być systemy hybrydowe.

\section{LITERATURA}

Barvell K, Risk and Developments in Payment Systems (2002), https://www.imf.org/external $/ \mathrm{np} / \mathrm{leg} / \mathrm{sem} / 2002 / \mathrm{cdmfl} / \mathrm{eng} / \mathrm{barvell} . p d f$ [26.04.2017].

Bech M.L., Preisig Ch. Soramäki K. (2008), Global Trends in Large-Value Payments, FRBNY Economic Policy Review September, Federal Reserve Bank,New York. 
Glossary of terms related to payment, clearing and settlement systems, (2009), European Central Bank.

Górka J. (2013). Efektywność instrumentów płatniczych w Polsce, Wydawnictwo Naukowe Uniwersytetu Warszawskiego, Warszawa.

Iwańczuk A. (2011), Systemy płatnicze i rynek płatności w Unii Europejskiej, Wydawnictwo CeDeWu, Warszawa.

Khandelwal S. Risk in Large Value Payment Systems, Journal of Internet Banking and Commerce, Vol. 12, Nr. 1, 2007

Nadzór systemowy w zakresie systemu płatniczego (2017), Narodowy Bank Polski, Warszawa.

New developments in large-value payment systems, (2005), Committee on Payment and Settlement Systems, Bank for International Settlements, http://www.bis.org/cpmi/ publ/d67.pdf [27.04.2017].

Ocena funkcjonowania polskiego systemu płatniczego w II półroczu 2016 r. (2016). Narodowy Bank Polski. Warszawa.

Polityka sprawowania przez Narodowy Bank Polski nadzoru systemowego w zakresie systemu płatniczego, (2015), Departament Systemu Płatniczego, Narodowy Bank Polski, Warszawa.

Rozporzadzenie Europejskiego Banku Centralnego (UE), w sprawie wymogów nadzorczych w odniesieniu do systemów płatności o znaczeniu systemowym. nr 795/2014 $\mathrm{z}$ dnia 3 lipca $2014 \mathrm{r}$

System płatności natychmiastowych - analiza wybranych systemów, rola banku centralnego oraz kierunków rozwoju, Narodowy Bank Polski, Warszawa 2015.

Tochmański A. (2013), Miejsce obrotu bezgotówkowego w systemie ptatniczym, [w:] H. Żukowska, M. Żukowski (red.), Obrót bezgotówkowy w Polsce, Wydawnictwo KUL, Lublin.

Wilson M. (2004), Real-Time Gross Settlement and hybrid payment systems: a comparison, Bank of England Working Paper 252.

White paper: Reducing risk and increasing resilience in RTGS payment systems (2014), www.swift.com [27.04.2017].

\title{
RISK MANAGMENT IN PAYMENT SYSTEMS
}

\begin{abstract}
In this article author attempted to characterizes the main types of risk which may occur in the payment systems and the major mechanisms proper to reduce their effects. In this publication major accent was placed on the analysis of large-value payment systems. This kind of systems because of their strong correlation with retail systems are considered like a form of protection against extension of systematic risk. This article is a form of theoretical revue witch base on literature analysis, reports, and the legal acts concerning payment systems.
\end{abstract}

Keywords: payment system, large-value payment systems, RTGS, DNS 
